\title{
Три ћирилска рукописа некадашње православне цркве у Адоњу
}

\author{
ДИМИТРИЈЕ Е. СТЕФАНОВИЋ \\ Dimitrije STEFAnović, ELTE Szláv Tanszék, Budapest, Múzeum krt. 4/D, H-1088
}

\begin{abstract}
The study describes three Church Slavic manuscript liturgical books (a Tetra Gospel from the last decade of the 16th century, a Triodion from the second quarter of the 16th century, a Ritual commemorating the transfer of St. Nicholas's relics from 1594 and an Octoechos from the turn of the 16th and 17th centuries.
\end{abstract}

Keywords: description of manuscripts, the orthodox church of Adony, Székesfehérvár

Међу многим старинама које се чувају у културним установама Стоног Београда (Székesfehérvár, Фејерска жупанија, Мађарска) налазе се и три стара ћирилска рукописа која ћемо у овом раду описати. Два, Четворојеванђеље из последње деценије XVI века; Триод иветни из друге четвртине XVI века, похрањена су у Музеју «Свети краљ Стефан» (Szent István Király Múzeum), а Служба преносу моштију св. Николе и Октоих првогласник (конволут) из 1594. године, односно из последње деценије XVI или почетка XVII века чува се у Бискупској библиотеци (Püspöki Könyvtár).

У судбини та три рукописа, између осталог, заједничко је да су 1913. године, са више десетина ћирилских и грчких штампаних књига, једном рачунском књигом и неколико икона, из места Адоња (Adony, Фејерска жупанија) доспела у стонобеоградски Музеј «Свети краљ Стефан». Књиге и предмети некада су припадали српској православној цркви у Адоњу, која данас више не постоји. Наведене године, у оквиру једне акције скупљања старина (Фејерске жупаније) они су уз подршку локалних угледника пренесени из Адоња у Музеј'. Од три кодекса један, који садржи Службу преносу моштију св. Николе и Октоих првогласник, од седамдесетих година нашег века сврстан је међу књиге Бискупске библиотеке 2 .

Место Адоњ лежи на десној обали Дунава, педесетак километара јужно од Будимпеште. У последњим деценијама XVII века, извесно време, носило је назив Рацадоњ (Rácadony). Крајем XIX века, када због промењеног етничког састава становништва наведени назив више није био актуалан, насеље је, на одређено време, названо Дунаадоњом (Dunaadony). Данас опет носи ранији назив Адоњ 3 . У ранијим српским, али и

1 Тај део судбине три рукописа и осталих књига и предмета детаљније је истражио др Калман Бор (Bor Kálmán), пензионисани сарадник Националне библиотеке «Сечењи». Податке преносимо на основу његових бележака, које нам је љубазно уступио.

2 O томе нам је податак љубазно саопштио др Гергељ Мозеши (Mózessy Gergely), управник Бискупске библиотеке у Стоном Београду.

${ }^{3}$ LENDVAY Zoltán, Adony a történelemben. Adony 1996, 34; 154-155. 
другим изворима, поред облика Адон, користио се и турски назив Џанкуртаран (тур. cankurtaran - 'који спасава душу, живот'), како се заправо звало утврђење у близини оновременог насеља на чијем месту се развио савремени Адоњ, ${ }^{4}$ као и разне изговорне варијанте тог турског облика: Жанкуртаран, Чанкуртаран и сл. У каснијим изворима, као и литератури јавља се и Едун или Едуна 5 и уобичајено Адоњ.

Историјско насеље на Дунаву православни Срби су још у турско доба настанили 6 . Православној заједници у Адоњу, неко време, припадали су и Грци. На то упућују и поменуте грчке књиге из некадашње адоњске цркве. У литератури се спомиње неколико адоњских Грка трговаца средином XVIII века7.

У одговарајућим записима два актуална рукописа казује се како су она 27. јануара 1732. године из сентадрејске Ћипровачке цркве поклоњена цркви св. Тројице у Адоњу ${ }^{8}$, што упућује на то да је у наведено време ту стајао освећени храм. Објављена документа световних и римокаточичких црквених власти из 1734. године показују да је градња «новоподигнуте» православне цркве у насељу трајала дуже времена, али је још и наведене године оспоравана ${ }^{9}$. Тако су рукописи поклоњени цркви чија је изградња завершена пре тог поклањања, можда 1731. године или раније. 20. маја 1812. у Адоњу су «при пароху Андреју Радановићу и епитропу Науму Козмановићу» почели нову цркву зидати, да би већ 14. септембра исте године крст на њој подигли ${ }^{10}$. У тој години је и број православних нагло порастао и то је трајало до 1818. После 1819. њихов број нагло опада ${ }^{11}$. Црква је 1887. године обновљена, али број православних домова у Адоњу свео се на два, а душа на осамнаест12. У Другом светском рату (у зиму 1944-1945) зграда цркве је тешко оштећена, тако да се касније морала срушити ${ }^{13}$.

У опису појединих рукописа палеографску и језичку анализу урадили смо на основу читања текста на неколико страница, као што је то уобичајено при изради «средњих» описа, а не на основу провере целог

${ }^{4}$ BÓNA István, Dunapentele története. Budapest 1991, 15.

5 Д. J. Поповић, Велика сеоба Срба - Срби сељаци и племићи. Београд 1954, 36.

${ }^{6}$ LENDVAY Zoltán, нав. дело.

${ }^{7}$ FÜVES Ödön, Görög kereskedők a Dunántúlon 1754-1771 között: Antik tanulmányok, XII/1. Budapest 1965, 107; LENDVAY Zoltán, нав. дело, 58.

8 Четворојеванђеље л 4; Служба преносу моштију св. Николе са Октоихом првогласником л 2.

${ }^{9}$ С. Гавриловић, И. Јакиић, Грађа о православним црквама Карловачке митрополије XVIII века: Споменик, СXXIII, Одељење историјских наука, 2. Београд 1981, 13-17.

10 Матична књига умрлих цркве Силаска св. Духа, година 1775-1860, Архив Српске православне епархије будимске, Сентандреја, унутрашња страна задње корице.

11 LENDVAY Zoltán, нав. дело, 95.

12 Г. Марјановић, Први шематизам Православне српске епархије будимске за годину 1896. Сремски Карловци 1896, 71-72.

13 Из бележака господина Калмана Бора. 
кодекса. Анализирајући правопис споменика, условно смо употребили традиционалне називе «рашка» и «ресавска» за одговарајуће ортографске школе раније српске писмености. Ти називи, међутим, не имплицирају географско порекло споменика, већ само спровођење одређених правописних узуса. При представљању садржина црквенословенске цитате наводимо или оригиналном црквеном ћирилицом или у транскрипцији савременом српском ћирилицом. У записима смо скраћенице разрешили у угластим заградама, а за ауторске интервенције користили смо полукружне заграде. При разрешењу скраћеница могу се појавити недоследности у оним случајевима када је језик записа хибридан (са елементима српскословенског, рускословенског или српског народног језика).

Поводом објављивања овог рада захвалност дугујемо господину Калману Бору, пензионисаном сараднику Националне библиотеке «Сечењи» у Будимпешти, који нам је скренуо пажњу на рукописе у Стоном Београду и пренео нам резултате својих ранијих необјављених истраживања у вези са њима. Исто тако захвалност изражавамо колеги Радоману Станковићу, саветнику Археографског одељења Народне библиотеке Србије у Београду, који је идентификовао водене знаке у појединим кодексима.

Фотографије је израдио господин Иван Јакшић, фотограф при Српским народним новинама у Будимпешти, коме такође захваљујемо на доброј вољи.

При припреми ових описа имали смо колегијалну подршку сарадника двеју стонобеоградских библиотека у којима се рукописи чувају, као и Црквеноуметничке збирке Српске православне епархије будимске у Сентандреји.

\section{Музеј «Свети краљ Стефан», Стони Београд (Szent István Király Múzeum, Székesfehérvár)}

(1) Четворојеванђеље, последња деценија XVI века

Инв. број: 567/1913

Текст рукописа на папиру, број листова: III+293+III, димензије листа: $305 \times 205$ мм, димензије текста на страни: $205 \times 125$ мм, број редова у основном тексту 21 , у осталим деловима садржаја променљив. Старија фолијација словима црквене азбуке у бројној вредности од $\tilde{\boldsymbol{a}}$ до $\tilde{\boldsymbol{\rho}}$. После л $\widetilde{\theta}$ следи неозначени лист. Кодекс има 37 свезака: ${ }^{8}-X_{X X V I}{ }^{8}$, XXXVII ${ }^{5}$. Већина ознака свезака по средини доње маргине сачувана је. Прва и последња три листа су прикорична и унесена су приликом најновије рестаурације 1997. године. Листови 9', 10 нису исписани због квалитета хартије, такође ни на листовима 81' и 293' нема основног текста. Новија фолијација графитном оловком. 
Писар кодекса није познат. Не зна се ни место ни тачно време писања. У запису на л 4' казује се да су ликови јеванђелиста насликани 1597. године. То значи да је рукопис исписан до назначеног времена сликања минијатура. На последњу деценију XVI века упућују и водени знаци.

Од водених знакова нађена је само једнострука котва у кругу са угластим тролистом и контрамарком $C B$, врло сличан, скоро идентичан: Мошин 277 из 1590-1600. године ${ }^{14}$; Никољац 8 из 1592. године ${ }^{15}$; Цетиње 8 око 1600. године ${ }^{16}$.

Рукопис је исписан правилним полууставним писмом са очигледним калиграфским тежњама. У основном тексту слова су крупнија и издужена, у осталим деловима текста она су ситнија и квадраста са више брзописних надредних слова. Нарочито у основном тексту писар настоји да опонаша за његово време већ архаичне узоре уставног писма. Словни облици ређе варирају. Број лигатура је минималан. У основне карактеристике овог писма спадају и дебљи вертиклни и тањи хоризонтални потези слова. Слово а има улево нагнуто стабло чији се доњи део обавезно спушта испод линије, узана петља стабло додирује у његовом средњем делу и спушта се до доње линије; к са горњом пречком, на чијем крају је карактеристични висак, она је увек дужа од доње линије редуковане петље; в има смањену горњу петљу која се у горњем делу усправног стабла додирује са доњом петљом; $\boldsymbol{A}$ са два благо искошена стабла која се састају на горњој линији, врх је заравњен, хоризонтална пречка је прилично дуга, ножице су косе и спуштају се дубоко испод доње линије; є има уску и широку варијанту; ж је тропотезно са мање или више редукованим горњим делом и са често асиметричном левом и десном половином; s је као развучено латиничко $s$; 3 са горњим делом који чине удесно нагнуто стабло и хоризонтална пречка са виском на левом крају и доњим извијеним делом који се спушта дубоко између два реда и додирује стабло негде изнад доње линије; и има два вертикална стабла, једва искошена пречка се налази мало изнад средине; поред уставног облика м са искошеним спољашњим стаблима и унутрашњим делом који под оштрим углом додирује доњу линију, јавља се међу надредним словима рубрика слично обликовано брзописно м; поред елипсастог о јавља се и широко почетно О; п има пречку која увек прелази висину десног стабла; поред диграма оу и праве лигатуре 8 , јавља се и љ као непотпуна лигатура; поред уставног облика $x$ јавља се танким цртама исписани развучени брзописни облик; ч је једнострано, налик на број четири са доста редукованим горњим делом; поред

14 V. MOŠIN, Anchor watermarks: Monumenta Chartae Papyraceae Historiam Illustrantia, XIII. Amsterdam 1973.

15 P. Станковић, Датирање и водени знаци рукописних књига манастира Никољца: Археографски прилози 16 (Београд 1991) 141-306.

16 П. Момировић, Љ. Васиљев, Ћириличке рукописне књиге Цетињског манастира XIV-XVIII века. Цетиње 1991, 32. 
уставног облика ь са ситнијом петљом, као варијанта у одређеној позицији, јавља се «високо јер» са високим удесно искошеним стаблом и угнутом пречком улево; поред уставног облика $\mathbf{k}$, чије се стабло диже високо изнад горње линије и чији вискови на пречкама, које су положене у висини горњег реда, могу бити једнаки или неједнаки, јавља се, обично на крају реда, издужено јат; $\omega$ има уставни облик са средњим стаблом до горње линије.

Овакво обликовање слова и њихових сразмерно ретких варијаната одговара палеографском узусу у време настанка рукописа. У духу тог времена су и она брзописна обележја која се јављају при писању мањих иницијала (пре свега $\mathbf{R}$ и $\mathbf{P})$. Међу њима се ређе уочава и лигатура $\mathbf{R}-\mathbf{k}$ (високо јер).

Језик рукописа је српскословенски (српска редакција старословенског). Правопис је претежно ресавски, с тим да су у неким сегментима изражене архаичније рашке ортографске црте.

На етимолошком месту старословенских ь и $\mathbf{~}$ у начелу пише се ь, али се уз тај знак као графијска варијанта појављује и високо јер. Знак ь се добро чува на крају предлога и префикса, где се у време писања текста налазио у фонетском положају (изговарао се као $а$ ). Само у истом положају уочени су примери и са високим ъ. На пример: вь 6, (ьнитн 6', вьсхот太 6', (ьтворн 6', вьстокь 7, (ь (предлог) 7; вһсхоть 6',

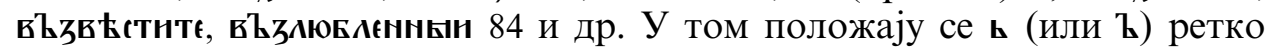
испушта. Знак ь се прилично доследно чува после крајњих сугласника. У ређим случајевима, међутим, испушта се испред енклитика, нпр. єюом жє 5', скоудет сє 6'. У средини речи (У основи и суфиксу) ь често није сачуван на етимолошким позицијама (у јаком и слобом положају), нпр. правєань 6', сн太 6, месту ь у средини, као и на крају речи, испред енклитика, понегде се

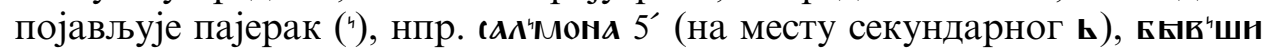

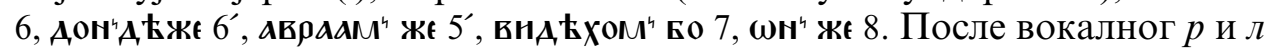

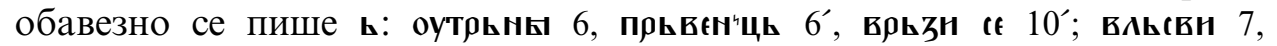
нспльнити 10.

Појава писања $\boldsymbol{a}$, као резултата српскословенске вокализације некадашњег полугласника (у јаком, а у неким случајевима и слабом положају), која је карактеристична за српскословенске рукописе и у XVI веку, у прегледаним деловима текста није уочена. На могућност постојања те појаве, међутим, упућује пример са ь на етимолошком месту вокала $a$ : вьвулонскоє $5^{\prime}$. Пример за старословенску вокализацију $\mathbf{b}>$ o је тогАа 8 .

На више начина се означавају прејотовани вокали $j a, j e$, а у страним речима и $j y$, као и ' $a$ и 'e после палаталних $л, t$. Групу јa на почетку речи означава само в; на почетку слога у речи: а (нарочито у карактеристичној ресавској групи їа), ређе в; после палаталних консонаната

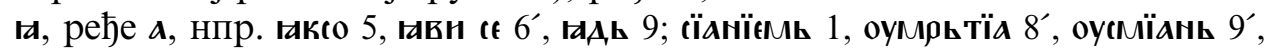




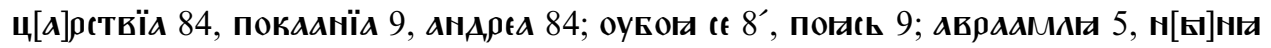
10, днвлtахоу єє 84, али и зоровавєла (присв. придев) 6. Групу је на почетку речи најчешће означава $є$; ређе є, сасвим ретко є; на почетку слога у речи Іє, є (нарочито у карактеристичној ресавској групи їє), ретко (обично у страним речима) є; после палаталних консонаната є, понекад є, нпр. єго 5, єъєкїю 5, єжє 6, єгдажє 7, єАнномь 10, є (заменица) 7, юст[ь ] 7',

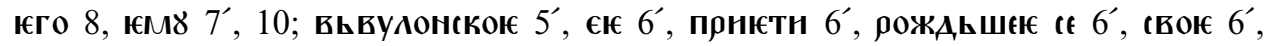

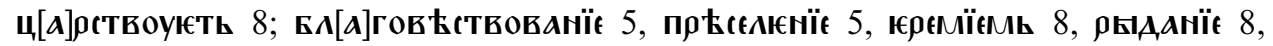

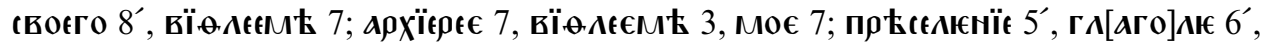
нз неє 6, Фгнємь 85, али и возлюкленнвн 10 . Группу jу означава ю, с тим да се у страним речима, поред најчешће ресавске групе їю, могу појавити їоу или ї४, напр. авї४Ал 6, єлїоуда 6. У рукопису се доследно чува архаична група чю.

Осим їа, їє и їю у ресавском правопису уобичајена је и група їн, која је представљена у примерима марїнна 6, нмоущїн 6, прїндошє 7, оучємїн 84 и др.

Слово ї пише се и између два консонанта у речима страног порекла, нпр. ішїфа 9, сїмона 84. Карактеристична је двојност почетних графијских група ї и и ређе нш у именима страног порекла.

Уочавају се примери са мешањем є и $\mathbf{k}:(\bar{\omega})$ оурнн $5^{\prime}$, і

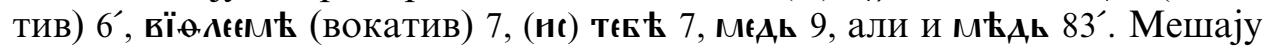
се и и в. У средини речи и се чешће налази на месту в, а у наставцима ь чешће заузима етимолошке позиције н: чєтнрн 1', кн (акузатив множне)

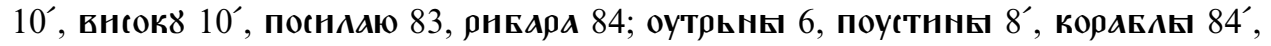
али скр чь 1'. Јавља се прелазак етимолошког и у в на почетку глаголске основе после префикса који се завршава на -з, нпр. нъкдє 84’, што је карактеристично и за раније текстове са ресавским правописом. Групе

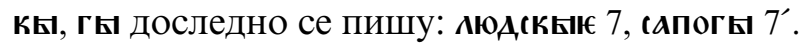

Слово s je на етимолошком месту у примерима: sъłъдоу 7, słло 8, али у примерима sмїє $1^{\prime}$, пюоугн 9 налази се на месту 3.

У речима страног порекла пишу се слова ө и: ншө ама 5', маөана 6, назарєе 8'; вьвулонскоє 5', єгуп'ть 8.

Почетно о означава се са $\omega$, широким о и обичним о. У средини и на крају речи $о$ се означава са $\omega$ (нарочито у речима страног порекла) и о. На почетку речи $y$ се пише као диграм оу, а ређе и као неправа лигатура ґ, у средини и на крају речи пише се као оу, в и ж.

Примери удвајања вокалских слова: мкнхь 7, мкыхқ 7, кл[а]говолї-

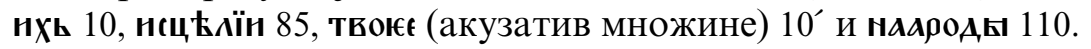

Неке од морфолошких и синтаксичких црта: архаични облик акузатива код именица мушког рода којима се означавају жива бића, нпр.

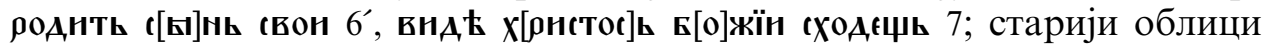
партиципа претерита код глагола са презентском основом на $u$, нпр.

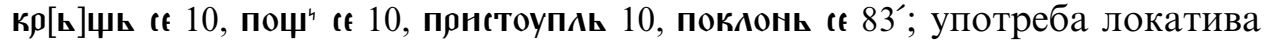
после глагола кретања, што је наслеђено из неких од старословенских 


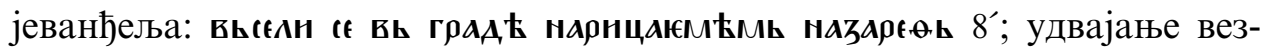

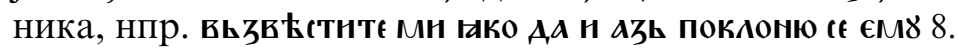

Надредни спиритуси и акиенти преузети су из грчког, с тим што су изгубили првобитну функцију. Њихова сразмерно доследна употреба у духу је ресавског правописа. Спиритус ленис (') изнад почетног вокалског слова једносложних и вишесложних речи. Од акцената оксија (’) изнад почетних вокалских слова, обично у комбинацији са спиритусом ('), као и изнад вокалских слова у средини речи, варија (') најчешће изнад крајњих вокалских слова (и у енклитикама), периспомени (`), који се по обликовању тешко разликује од спиритус лениса, обично се налази изнад прејотованих, а ређе и других вокалских слова у средини речи; двострука варија (") изнад ь и других вокалских слова на крају једносложних речи.

Титле за означавање скраћеница и скраћено писаних речи, као и пајерици на месту испуштених јерова обликују се на више начина.

Од интерпункиијских знакова користе се крупнија киноварна тачка у основном делу текста, обична мрка тачка у осталим деловима, као и зарез. На крају већих садржинских целина најчешће се јављају три црвене тачке са завршном извијеном цртицом, исте боје као и тачке.

У илуминаиији рукописа писар, као и сликар минијатура, тежи да оствари естетске домете. Уставни потези при обликовању већине слова, колорит, вично изведене велике вињете и други елементи украса достојно треба да представљају основну садржину кодекса. Јеванђеље се налази на највишем месту у хијерархији жанрова византијско-словенске црквене књижевности. У опремању рукописа писар и илуминатор, као и многи њихови савременици, угледали су се на узоре из XIV века.

Већи део текста исписан је мастилом мрке боје; живе главе, контуре већих иницијала, мањи иницијали и иницијална слова, нека велика слова, рубрике, маргиналне ознаке читања, маргинални цртежи, контуре табела киноваром. При писању неких од главних наслова користи се и злато, као што се при извођењу неких од живих глава, наслова и маргиналних ознака читања користи и мастило плаве или златне боје.

Мањи брзописно обликовани иницијали (пре свега $\mathbf{R}$ и $\boldsymbol{P}$ ) висине су од једног и по до два реда. Понекад су скромно украшени пречком или тачком на стаблу. Већи раскошнији иницијали на почетку појединих јеванђеља (л $5,84,135,221)$ висине су од четири до седам редова. Њихову илуминицију чине плетене траке и биљни мотиви. Између контура смеђе или црвене боје колорисани су златном, црвеном, зеленом и бордо бојом. Једноставнији геометријски иницијал изведен црвеним мастилом налази се на почетку Јеванђеља по Луки (л 135). Сви већи иницијали украшени су карактеристичним пречкицама, прстеновима, тачкама, висковима и др.

Мање заставице (л 1,134$)$ у неовизантијском стилу са мотивама плетења и биљним стилизацијама. Четири веће, различито компоно- 
ване заставице, величине од пола стране, испред почетака појединих јеванђеља (л $5,84,135,221)$ изведене су такође у неовизантијском стилу са мотивима плетења, биљним стилизацијама, као и геометријским облицима. Површине су колорисане црвеном, златном, бордо, зеленом, окер и плавом бојом.

Четири минијатуре јеванђелиста различите величине налазе се на ректо странама пре почетка текстова појединих јеванђеља. На минијатурама осликани су седећи ликови јеванђелиста, карактеристични симболи појединих еванђелиста, који нису дистрибуирани на традиционалан начин, као и стални архитектонски мотиви. Представе су богато колорисане бојама и нијансама боја. Сигнације уз поједине минијатуре:

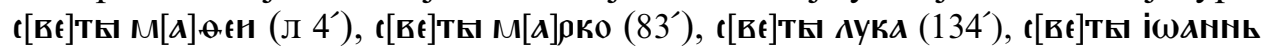
(22').

Према запису (4’) минијатуре је осликао поп Страхиња 1597. године. Он је био знаменити сликар краја XVI и првих деценија XVII века. Радио је фреске у десетак цркава и бавио се иконописом ${ }^{17}$. Представе ликова четири јеванђелиста у рукопису из некадашње адоњске цркве откривају га и као минијатуристу ${ }^{18}$.

Кодекс садржи текст Четворојеванђеља (јеванђеља у канонском библијском поретку), прилагођен богослужбеној употреби.

л 1 - Теофилактов предговор Јеванђељу по Матеју.

л 2'- Главе Јеванђеља по Матеју; л 4' - минијатура јеванђелиста Матеја са записом сликара.

л 5 - Јеванђеље по Матеју; л 81 - поговор Јеванђељу.

л 82 - Теофилактов предговор Јеванђељу по Марку.

л 82' - Главе Јеванђеља по Марку; л 83’ - минијатура јеванђелиста

Марка.

л 84 - Јеванђеља по Марку; л 131' - поговор Јеванђељу.

л 132 - Теофилактов предговор Јеванђељу по Луки.

л 133 - Главе јеванђеља по Луки; л 134'- минијатура јеванђелиста Луке.

л 135 - Јеванђеље по Луки; л 218' - поговор Јеванђељу.

л 219 - Теофилактов предговор Јеванђељу по Јовану.

л 220 - Главе јеванђеља по Јовану; л 220' - минијатура јеванђелиста

Јована.

л 221 - Јеванђеље по Јовану.

л 284 - Распоред читања јеванђеља преко целе године, почев од Велике недеље.

л 289 - Саборник (месецослов).

17 C. Петковић, Делатност зографа попа Страхиње из Будимља: Годишњак Завода за заштиту споменика културе, Старине Црне Горе, I. Цетиње 1963, 113-127; исти aутор, Српска уметност у XVI и XVII веку. Српска књижевна задруга, 589, Београд 1995, 91-92.

18 То нам је саопштио професор др Сретен Петковић (Филозофски факултет у Београду). На његовом љубазном саопштењу и овога пута се захваљујемо.

Studia Slavica Hung. 46, 2001 